\title{
Why Revitalize? Labour's Urgent Mission in a Contested Global Economy
}

\author{
Lowell Turner
}

Cornell University

What looked like carte blanche for corporate-led globalization just a few years ago is now increasingly contested. The brave new vision of market fundamentalism has been challenged on several fronts, from massive demonstrations in Seattle and Genoa to contested trade and environmental summits at Johannesburg and Cancun. The critical insights of highly placed insiders have undermined the dominant neo-liberal ideology and given credence to mounting protests and opposition viewpoints (e.g. Soros 2002; Stiglitz 2002). Economic stagnation, inequality, desperate poverty and violencewhether in Japan, East Asia, Russia, Germany, or the United States and Latin America-have belied optimistic predictions of the positive effects of unbridled globalization. Economic policy makers from the rich countries are challenged both by domestic opposition and by a growing reluctance in the global South to acquiesce in one-sided trade deals. The future shape of the global economy and its international, as well as national and local economic policies, are now open to widespread and growing debate.

Yet, debate is clearly not enough. What is also required are strong organized actors to promote alternative viewpoints and to build the progressive coalitions-global, national, and local-that can turn policy around. While together they cannot yet match the power of multinational corporations (even if they could act together consistently), many such actors are already present, and many of them are increasingly ready to contest the dominant policies. Opposition forces include a broad range of international and domestic non-governmental organizations (NGOs), from environmental to health and human rights groups, swelling protest movements from global justice, and antiwar to land reform, from Jose-Bove-inspired farmers to religious and cultural defence movements, as well as increasingly independent governments across the global South (from Brazil and Argentina to South Africa, India, and China). And one clearly indispensable actor in present and future reform efforts is organized labour, the subject of this book.

\section{THE URGENT NEED FOR LABOUR MOVEMENT REVITALIZATION}

Because unions represent-or seek to represent-vast numbers of the earth's 'have- nots' and a large number of 'have-somes' as well (e.g. workers in the global North), progressive coalitions and initiatives are greatly strengthened with the inclusion of labour. On the other hand, when unions operate as special interest groups, defending only their members and in some cases even opposing environmental, civil rights, or other reform efforts, the prospects for progressive economic policies are greatly diminished. Indeed, it is difficult to imagine transformation of global, national, and even local economies, including a reversal of the deep inequality that threatens both global and domestic peace, without the broad, proactive participation of labour in campaigns for reform. It is equally difficult to imagine preservation of the earth and a broadening of human rights unless unions join such coalitions as enthusiastic proponents and partners. This is why 
we believe that labour movement revitalization is such a critical contemporary task, one worthy of support through research that specifies the pros and cons of alternative strategies and points towards mutual learning and policy recommendations for unions, governments, and other actors.

Beyond recurrent employer and government opposition, there are at least two critical problems for a broadened labour participation in global, national, and local reform efforts. One is when unions take a narrow perspective and fail to develop the linkages, alliances, and broad reform vision required to build the necessary political power. The other is the widespread contemporary problem of union decline. Labour revitalization studies seek above all to identify strategies that can both broaden the perspective and reverse the decline. And our research persuades us of a close connection between the two, namely that a broadened perspective and more comprehensive strategic focus are necessary to reverse the decline of organized labour. With five country teams of researchers, our specific focus is on unions in the United Kingdom, the United States, Germany, Italy, and Spain. But we also believe that our findings and analysis have relevance throughout the global North, and that some of the same lessons could also be applied in the very different (and much more difficult) circumstances of the global South.

Our focus, therefore, is on actor strategies, and especially on the strategies of unions: national, sectoral, and local unions as well as national labour federations. Studies of union decline, of which there have been hundreds over the past two decades, are important, but this is not our task. We assume that the basic facts about union decline are no longer controversial; union leaders in all of our countries (and many more) acknowledge either the reality of protracted decline (the United States and United Kingdom) or the pressure from employers and neo-liberal economic policy that threatens decline (Germany, Italy, and Spain). And the causal factors driving decline have been specified, analysed, and widely debated (from Kochan, Katz, and McKersie 1986 to Kelly 1998 and beyond).

\section{CONTEMPORARY PERSPECTIVES: FOCUS ON EMPLOYERS}

Postwar labour scholarship, in the industrial relations and comparative political economy literatures, has emphasized institutional configurations and bargaining relationships (see also Baccaro, Hamann, and Turner 2003: 12528). Two of the most recent and prominent of these perspectives-known to scholars as 'transformation of industrial relations' (Kochan, Katz, and McKersie 1986) and'varieties of capitalism' (Hall and Soskice 2001) -illustrate where these literatures have arrived. Traditional industrial relations literature, especially but not only in the United States, talks about system stability, contracts and laws, and regularized bargaining relationships, but tells us little about what to do when the system approaches collapse (Kerr et al. 1960; Slichter, Healey, and Livernash 1960). The transformation literature of the 1980 s and 1990s, by contrast, makes a valuable contribution in analysing collapse, especially in the United States, and identifying employer opposition as the driving causal force in system instability and union decline (Kochan, Katz, and McKersie 1986). The recent varieties of capitalism literature builds both on earlier institutional approaches and more recent transformation literature to show the very limited possibilities for union influence in liberal market economies (LMEs) such as the United States and the United Kingdom, in contrast to more substantial union roles in coordinated market economies (CMEs), although even here unions are either incorporated and weak (Japan) or under new pressure 
and in danger of decline (Germany) (Hall and Soskice 2001; Thelen 2001).

The problem with all of these views is that they assign union strategy a secondary place. Union strategies may matter, but they are either derivative of institutional frameworks or they are overwhelmed by opposing forces. Unions can adapt - to the institutions or the transformation, by collaborating with employers largely on management's termsbut they cannot pursue innovative strategies to promote a worker-friendly transformation of their own. This is true to a large extent in the varieties of literature even for CMEs (Hall and Soskice 2001; Swenson 2002); for LMEs there is little prospect for meaningful, independent union influence (Thelen 2001). Yet renewed transformation, to challenge employer dominance and broaden union influence, is precisely what innovative contemporary unions seek. For unions pursuing renewed influence both at work and in the broader society, proactive strategies matter a great deal. Today's revitalization literature aims to understand (and promote) the new proactive strategies, for which the received literature tells us all too little. Still in its early days, theoretically underdeveloped and incorporating conflicting currents, this recent work on union strategies offers rich promise for theoretical breakthroughs and policy prescriptions, based on new understandings of how unions can best influence contemporary developments (cf. Bronfenbrenner et al. 1998; Kelly 1998; Turner, Katz, and Hurd 2001; Nissen 2002; Turner 2003; Cornfield and McCammon 2003) ${ }^{1}$ It is to this growing body of scholarship that we seek to contribute.

Ours is a synthetic view, in contrast to zero-sum debates between cooperationists and militants, between activism and participation, between social partners and organizers (cf. Kochan 1995; Moody 1997). Whether union strategies aim at promoting participation in the production of high value-added goods and services, political power for broad economic reform, or basic organization and dignity for low wage service workers, successful outcomes depend on union strength, and especially on renewed organizing and mobilizing capacity. Moreover, the institutional reform necessary to stabilize worker dignity and participation throughout the whole labour market- from labour law reform to corporate accountability and improved social policy-is inconceivable in the absence of sustained popular pressure from labour and its allies.

\section{STRATEGIES FOR LABOUR MOVEMENT RENEWAL}

\section{IN A GLOBAL ECONOMY}

The most significant revitalization strategies identified in our country cases are organizing, labour-management partnership, political action, reform of union structures, coalition-building, and international solidarity. Strategies overlap and are combined in various ways (e.g. in comprehensive campaigns: see Hickey 2003), so that the interactions inevitably push their way into our analyses. Particular strategies are more or less important in different countries, and we attempt to analyse and explain the differences. Above all, we are interested in the ways in which these strategies combine to magnify the reform efforts of unions and their allies, as well as the conditions for success in different national and local settings.

The impact of globalization, and especially the market fundamentalist policies shaping contemporary world markets, means that unions are more often than not under pressure (if not open attack), from employers, governments, 
or both. Fighting back with one or two piecemeal strategies, no matter how innovative and intensive, is unlikely to reverse the tide. Nor is the panoply of conventional approaches. Unions, we argue, need a bigger tool kit, a range of strategies new and old that ean be combined and recombined to escalate the counter-pressure and increase the prospects for resurgence and reform.

Partnership and mobilization, for example, can be (and often have been) dead-end strategies when taken alone. While they each tend to attract proponents who favour one and dislike the other (cf. Kochan 1995; Kelly 1998), both may well be necessary elements of sustained labour movement revitalization (Boxall and Haynes 1997). In intensified efforts to reverse decline, many unions today, building on broadened perspectives, seek Virtuous linkages' among alternative strategies. Expanded coalitionbuilding, for example, can broaden labour's political influence, which in turn can provide new support for union organizing. ${ }^{2}$ Political and organizing success can then encourage rank-and-file mobilization and sustained relations of partnership. We look for the conditions under which such virtuous circles emerge, as well as the conditions that result in contrasting vicious circles-as when labour-management partnership results in workforce demobilization, undermining the prospects for both organizing success and political influence.

\section{ACTORS AND STRATEGIES}

The focus of this book is on actors and strategies: unions, coalitions, social movements, and related organizations, in politics and at the workplace, refocused on strategic innovations and renewed solidarity. Implicit in this perspective is the notion that unions must take responsibility for both internal reforms and innovative external strategies necessary to promote revitalization in today's extraordinarily difficult context. It will not do labour any good (beyond catharsis) to blame employers or governments - for everything from union decline to massive economic and social inequality (although employers and governments are very much responsible)-unless labour is also confronting the reality that new strategies and organizational reforms, new linkages and coalitions, are what unions require if present circumstances are to be turned around. The desired transformation is a task for mobilization, strategic participation, and a greatly broadened field of solidarity (from politics to local coalitions to international collaboration).

Our goal is to produce research and analysis that points towards policy implications for unions and their allies. In focusing on strategic innovations and campaigns, our hope is to assess the sources and relative merits of successful strategies and to demonstrate the conditions under which success and failure are likely, while at the same time capturing the very real drama and intensity of these events. The need for labour movement revitalization is urgent and we believe that researchers sympathetic to labour have an important contribution to make.

\section{CASE SELECTION AND CENTRAL FINDINGS}

In choosing the United Kingdom, the United States, Germany, Italy, and Spain, we have studied contemporary labour movement revitalization in all of the large advanced industrial societies with the exception of Japan and France. We have looked at two LMEs (the United Kingdom and the United States), one CME (Germany), and two 'Mediterranean' economies (Italy and Spain). And in this book we have moved beyond the conventional country case presentations to present cross-national comparative analysis of strategic innovation. As sketched out earlier, we have found six strategies 
that merit close consideration (organizing, labour-management partnership, political action, reform of union structures, coalition-building, and international solidarity). Repertoires of strategies vary significantly across both unions and countries. The book is organized around the strategies, one chapter for each, comparing their development, priority, use, and relative success across our five countries.

One lesson from this research collaboration is that unions have a broader range of strategic choice than most of us have imagined. In the United Kingdom, debates among resurgent militants, 'new unionism' organizers, and would-be social partners have only intensified under a Labour government, reflecting contending approaches to labour movement renewal (Heery, Kelly, and Waddington 2003). New union leadership in the United States, fighting the most serious decline of any of our country cases, has directed substantial resources towards innovative revitalization strategies, especially organizing, political action and coalition-building (Voss and Sherman 2000; Hurd, Milkman, and Turner 2003). Mobilization and coalition-building efforts have succeeded dramatically in some cases, from a UPS strike victory in 1997 to the Battle of Seattle in 1999, from Justice for Janitors to widespread living wage and antisweatshop campaigns. Yet, revitalization is concentrated in the strategies of the American Federation of Labor-Congress of Industrial Organizations (AFL-CIO) and several activist unions, with much of the labour movement as yet unreformed, even in the face of a renewed attack on labour from the Bush government and continuing union membership decline.

In Germany, unions have maintained their central position in the political economy by virtue of strong institutions, backed by mobilization capacity, in codetermination and comprehensive collective bargaining (Behrens, Fichter, and Frege 2003). Yet, intensified market competition, European integration, economic restructuring, and contemporary policy reform initiatives have challenged unions to move beyond traditional repertoires and institutional anchors to mobilize in innovative ways. The collapse of IG Metalls strike in eastern Germany in mid-2003 intensified debates between modernizers and traditionalists, perhaps opening the door for future organizational and strategic reform. The rise and fall and rise again of unions in Italy, from the Hot Autumn of 1969 through political transformation in the 1990s, has provided recurrent dramas of renewal (Baccaro, Carrieri, and Damiano 2003). The three major union confederations coalesced to play a leading role in the reconfiguration of Italian politics after the deep political crisis of 1993-94. While the Berlusconi government elected in 2001 brought union-led reform efforts to a halt, unions remained strong centres of opposition as well as entrenched actors in collective bargaining, shop floor representation, and workforce mobilization. In the newest democracy among our five country cases, Spain, where free trade unionism in its contemporary form is not yet 30 years old, opposing union confederations have collaborated to shore up their institutional position (Hamann and Martinez Lucio 2003). They have done this at the workplace, where they compete in works council elections, and in national politics, where they have bargained with parties, governments, and employers for institutional responsibilities. With some success at both levels, the result has been modest growth in union membership and stabilization of union influence.

\section{INSTITUTIONS AND MOBILIZATION}

Thus we find active efforts at labour movement revitalization everywhere in the global North, driven by globalization, intensified competition, neo-liberal economic policy (inspired by a US-led market fundamentalist ideology), 
employer and government opposition. In every case, there is experimentation, innovation, and wide-ranging internal debate regarding strategic direction and tactical choice. Because of fermentation and debate as well as contrasting institutional and political contexts, there is also great cross-national diversity of union strategy even in converging global and regional markets (Katz and Darbishire 2000). One useful distinction, at the broadest level of generalization, is between labour movements that focus revitalization effects on mobilization, and those that focus on institutional position and/or reform. Another look at our five country cases in this light reveals the following patterns.

The United Kingdom and the United States present the cases in which union strategies are most oriented towards mobilization-by no coincidence where the institutional position is weakest. British unions have acquired modest institutional support under the Blair government, without yet securing a position so entrenched that it could not be swept away by a Conservative government. Many activists focus on mobilization, either traditional militancy or innovative organizing, as the best route to institutional reform and influence. Others advocate social partnership with employers and/or collaboration with government, while the Trades Union Congress (TUC) struggles to maintain its umbrella over all of the contending parties. In spite of internal conflicts and limited government support (with gains for unions offset at least in part by ongoing privatization initiatives), union decline has been halted in the United Kingdom at around 30 per cent membership density amidst important signs of labour movement renewal and innovation. American unions have long advocated institutional reform (the 'labour law reform' debate), and see this as a prerequisite for broad growth in union membership. Yet, past reform efforts have failed in part because of weak mobilization of support. Current efforts in organizing, politics, and coalition-building seek to mobilize new support, with considerable promise and impressive success in particular areas (such as Las Vegas and Los Angeles) and particular industries (such as health care, building services, and telecommunications). The mobilization and political threshold beyond which meaningful institutional reform is possible remains nonetheless out of reach.

German unions have defended collective bargaining, codetermination, and the welfare state, under conservative and social-democratic governments alike, yet without the sustained mobilization necessary to promote a viable alternative vision for reform. The largest union, Ver.di, has consolidated through merger to defend public services and jobs, while the pattern-setting IG Metall appears divided and defensive in the wake of its first major strike defeat in 50 years. But German unions are now learning that when circumstances change-including intensified employer and government challenges in a context of globalization and European integration-established institutions may not be enough. To a certain extent, German unions have rested on their institutional laurels and lost touch with rank-and-file and broader social concerns. They may well be dependent now on renewed connections, grassroots leadership, and social coalitions to expand mobilization potential for the purpose of institutional reform, as the only viable alternative to institutional and organizational decline.

Italian unions have used political crisis and mobilization capacity to promote institutional reform, for both comprehensive collective bargaining and workplace representation, with considerable success over the past decade. Threats to hard-earned institutional position come from conservative economic policy as well as from union disunity (which the conservative government promotes in its labour market reform initiatives). Yet so far, Italian unions have 
maintained institutional strength while continuing to demonstrate vast mobilization capacity, helping to bring a million or more demonstrators out to protest against labour law reforms in 2002 and against the war in Iraq in 2003. Alongside new institutional stability, Spanish unions have also shown impressive mobilization capacity-bringing hundreds of thousands of demonstrators to Barcelona in 2002 to demand a stronger social Europe, and even larger numbers to Madrid in 2003 to protest against government support for war in Iraq. In doing so, unions have arguably deepened their popular base in Spain, at the same time underpinning and strengthening their enhanced institutional position.

While we are candid about the weaknesses and shortcomings of contemporary union strategies, everywhere we find experimentation and reform efforts, in many cases with new leadership and renewed vitality. There is widespread internal union debate, aimed at coalescing around appropriate strategies to renew mobilization and political influence, and to build, defend, or reform institutions of industrial relations. In all of our countries, for better and for worse, this is a time of contestation for labour unions, in the context of an urgent historical necessity for further strategic innovation. Such revitalization processes we would argue are exactly what unions need in the face of current challenges and uncertain outcomes and they are reflected in different combinations of strategies in different countries. While global capitalism skews the odds against labour, now and in the future, we nonetheless find cause for hope in the substantial union renewal efforts now underway in each of our country cases.

\section{ACKNOWLEDGEMENT}

This chapter was inspired by the work of a remarkable, collegial group of scholars engaged in comparative studies of labour movement revitalization, in several years of collaboration. For their comments and inspiration (although none of them Em quite sure would agree with everything in this introductory chapter-contentious, critical thinkers that they are), many, many thanks to my project colleagues: Lee Adler, Lucio Baccaro, Martin Behrens, Brigid Beachler, Mike Fichter, Carola Frege, lan Greer, Kerstin Hamann, Ed Heery, Rick Hurd, John Kelly, Nathan Lillie, Miguel Martinez Lucio, Ruth Milkman, Manfred Muster, Jeremy Waddington, and Kent Wong. A special thanks also to my research collaborators at

Cornell University (the Global Democracy Research Group), including Beachler, Greer, and Lillie as well as Marco Hauptmeier, Ritu Jain, Heiwon Kwon, and Julie Sadler; and to several other colleagues who attended our conferences and commented on our papers, including Peter Auer, Reiner Hoffmann, Richard Hyman, Otto Jacobi, A.V. Jose, Nik Simon, Wolfgang Streeck, Robert Taylor, and Peter Unterweger. Specifically for this introductory chapter, book editors Frege and Kelly offered insightful (if not always heeded) comments and suggestions.

\section{Notes}

1. See also the March 2003 special issue of the European Journal of Industrial Relations, featuring a series of chapters by the authors of this book, presenting revitalization research from each of our five countries (Baccaro, Carrieri, and Damiano 2003; Behrens, Fichter, and Frege 2003; Hamann and Martinez Lucio 2003; Heery, Kelly, and Waddington 2003; and Hurd, Milkman, and Turner 2003).

2. Unions in California, where legislative reforms have facilitated significant organizing successes in industries such as health care and agriculture, provide a contemporary case in point. 


\section{References}

Baccaro, L., Carrieri, M., and Damiano, C. (2003). 'The Resurgence of Italian Confederal Unions: Will It Last?'. European Journal of Industrial Relations, 9/1: 43-60.

-----Hamann, K., and Turner, L. (2003). 'The Politics of Labour Movement Revitalization:

The Need for a Revitalized Perspective'. European Journal of Industrial Relations, 9/1:119-33. Behrens, M., Fichter, M., and Frege, C. (2003). 'Unions in Germany: Regaining the Initiative?'.

European Journal of Industrial Relations, 9/1: 25-42.

Boxall, P. and Haynes, P. (1997). 'Strategy and Trade Union Effectiveness in a Neo-liberal Environment'. British Journal of Industrial Relations, 35/4: 567-91.

Bronfenbrenner, K., Friedman, S., Hurd, R. W., Oswald, R. A., and Seeber, R. L. (eds.) (1998).

Organizing to Win: New Research on Union Strategies. Ithaca, NY: ILR Press.

Cornfield, D. B. and McCammon, H. J. (eds.) (2003). Labor Revitalization: Global Perspectives and New Initiatives. Greenwich, CO: JAI Press.

Hall, P. A. and Soskice, D. (eds.) (2001). Varieties of Capitalism: The Institutional Foundations of Comparative Advantage. Oxford: Oxford University Press.

Hamann, K. and Lucio, M. M. (2003). 'Strategies of Union Revitalization in Spain: Negotiating Change and Fragmentation'. European Journal of Industrial Relations, 9/1: 61-78.

Heery, E., Kelly, J., and Waddington, J. (2003). 'Union Revitalization in Britain'. European Journal of Industrial Relations, 9/1: 79-98.

Hickey, R. (2003). Collective Bargaining Ruptures: Conflict and Control in an Oil Refinery. Ithaca, NY: Cornell University, Masters thesis.

Hurd, R., Milkman, R., and Turner, L. (2003). 'Reviving the American Labor Movement: Institutions and Mobilization'. European Journal of Industrial Relations, 9/1: 99-118.

Katz, H. C. and Darbishire, O. (2000). Converging Divergences: Worldwide Changes in Employment Systems. Ithaca, NY: Cornell University Press.

Kelly, J. (1998). Rethinking Industrial Relations: Mobilization, Collectivism and Long Waves. London: Routledge.

Kerr, C., Dunlop, J., Harbison, E, and Myers, C. (1960). Industrialism and Industrial Man.

Cambridge, MA: Harvard University Press.

Kochan, T. A. (1995). 'Using the Dunlop Report'. Industrial Relations, 34/3: 350-66.

----- Katz, H. C., and McKersie, R. B. (1986). The Transformation of American Industrial

Relations. New York: Basic Books.

Moody, K. (1997). Workers in a Lean World: Unions in the International Economy. New York: Verso.

Nissen, B. (ed.) (2002). Unions in a Globalized Environment. Armonk, NY: ME Sharpe. Slichter, S., Healey, J., and Livernash, R. E. (1960). The Impact of Collective Bargaining on Management. Washington, DC: Brookings Institution.

Soros, G. (2002). On Globalization. New York: Public Affairs.

Stiglitz, J. (2002). Globalization and its Discontents. London: Penguin Books.

Swenson, P. (2002). Capitalists Against Markets. Oxford: Oxford University Press.

Thelen, K. (2001). 'Varieties of Labor Politics in the Developed Democracies', in P. A. Hall and D. Soskice (eds.), Varieties of Capitalism: The Institutional Foundations of Comparative Advantage. Oxford: Oxford University Press, 71-103.

Turner, L. (2003). 'Reviving the Labor Movement: A Comparative Perspective', in D. B. Cornfield and H. J. McCammon 
(eds.), Labor Revitalization: Global Perspectives and New Initiatives. Greenwich, CO: JAI Press, 23-58.

-----Katz, H. C., and Hurd, R. W. (eds.) (2001). Rekindling the Movement: Labor's Quest for

Relevance in the 21st Century. Ithaca, NY: Cornell University Press.

Voss, K. and Sherman, R. (2000). 'Breaking the Iron Law of Oligarchy: Union Revitalization in the American Labor Movement'. American Journal of Sociology, 106/2: 303-49. 